\title{
The Role of the Accounting and Audit Standards in the Globalization Process
}

\author{
Eugenia Iancu ${ }^{1}$, Mihaela Tulvinschi ${ }^{2}$
}

\begin{abstract}
:
The audit rules are necessary, they being able to be useful as much for the auditors and for the audit beneficiaries. For the auditors, the rules make first of all a support item, a guide or a support in applying the methods, techniques, procedures and second of all a support and justification item, for the case where difficulties show up. In what regards third-parties, these will be assured that the audit is made by unitary criteria, no matter by whom it is made.

Even if solicited by various firms, in order to raise the credibility of the financial situations they published, the audit process cannot take place at random, without the existence of legal regulations. Due to the increasing importance the audit gets in developing any business, in time imposing the necessity to make professional specific standards, that are to insure a minimum quality of the audit process an a certain performance to the auditor profession.
\end{abstract}

Keywords: financial audit, accounting rules, international rules, certification standards, globalization process

JEL Classification:: M41, M42

\footnotetext{
${ }^{1}$ Stefan cel Mare University of Suceava, Universitatii Street, No.13, tel. +40 0230-520263, fax +40 0230-520263, Romania, eiancu@seap.usv.ro

2 Stefan cel Mare University of Suceava, Universitatii Street, No.13, tel. +40 0230-520263, fax +40 0230-520263, Romania, mihaelat@seap.usv.ro
} 


\section{Introduction}

\section{The National Audit Regulations}

In Romania, the audit as a regulated profession is known after the year 1990. More exactly, terms as "financial audit”, "financial auditor", "financial audit standards or regulations" have been introduced in our vocabulary after the adoption of the accounting law no. 82/1991, and also after publishing its appliance regulation in 1994.

Of a great importance for the further financial audit, financial auditor free profession, accounting expert and authorized accountant professions' development was publishing, in the Official Monitor no.243 of August 30 ${ }^{\text {th }}, 1994$ the Government Ordinance no. 65/1994 regarding organizing the accounting expertise and authorized accountants activities, approved by law no, 42/1995 referring to the attributions of the Romania Authorized Accountants and Accounting Experts Organizations (CECCAR) to make regulations regarding the professional activity an ethic behavior of the accounting experts and the authorized accountants.

The normalization efforts of the CECCAR, combined with the support of the academic specialists and the accounting commissioners from France had, as an effect, publishing the "Financial audit and accounting balance certification rules", due to the National CECCAR Conference Decision no.3 of October $23^{\text {rd }}$, 1995. The reference rules of the financial audit were classified as follows:

- $\quad$ accounting rules, or the common rules for all the ones that establish, control and use the accounts

- proper audit rules, or an assembly of rules established by the professional authority the auditor reports to in exerting his mission.

Also, the proper audit rules are divided in: professional working rules, opinion reporting rules and general professional behavior rules.

A problem that must be approached is connected to the audit normalization process. This process has, in general, 5 stages:

a) first of all, on a national level, there must be a normative document that establishes a professional organization, that disposes of disciplinary powers to its members; 
b) second of all, there must be an professional ethic code, that stipulates the obligation of the organization members to apply the rules in their missions and that stipulates creating an organization (committee, commission, workgroup) which has the task to make the rule project;

c) that organism makes or coordinates the research efforts and the necessary consultations, and presents a final version of the recommendations, version that is put under debates and is to be approved by the supreme forum of the professional organization (the only one that disposes of full control and punishment powers over its members);

d) those made rules become applicable, and for that the professional organization adopts adequate publishing, informing and forming means (courses, seminaries, debates);

e) the last episode of the audit normalization process is organizing the quality control. According to international practices, the external quality control can be organized on 3 ways:

- a first method is the one where any society or expertise/audit cabinet accepts to be periodically controlled (usually once every 3 years), friendly, by another society or profile cabinet;

- another method is the one that means direct involvement of the professional organization, that is the case where it specifies a number of cabinets or societies that accept to do, temporarily, only quality control; that means that the mentioned cabinets are not working, in the considered period of time, as normal audit or expertise cabinets, dedicating themselves only to the control of other cabinets or societies they must survey;

- finally, there is also the method where the professional organization creates, within its superior structures, a specialized organization (for example, the General Control Department of the CECCAR), which has own coordination personnel, but which can also used controllers submitted in the national list and section lists.

The applicable rules in the financial audit are: accounting rules, control rules and proper audit rules. These rules are supported by internal regulations, but also by international and European recommendations (Thalassinos, Liapis and Thalassinos, 2011a and 2011b). 
The accounting rules that must be respected for the audit are the common ones for all the ones that are involved in accounting, make accounting balances, verify, certify or use financial situations.

The control rules are an assembly of rules defined by an authority exterior to the expertise or audit cabinets, and can be a national or international cabinet. These rules will allow the use homogenous criteria and methods in all audit missions.

The audit rules are divided into three categories: general professional behavior rules, professional working rules and report rules.

The general rules determine the professionalism degree an auditor must comply with. Most of the external audit missions are made by people that comply with certain demands connected to professional experience. In most of the countries, people that wish to practice as auditors must adhere to an organization that is recognized for its professionalism in the domain. The more the audit users want a higher professional level of the auditors, the more exigent conditions will be imposed for a person to be part of the mentioned organization. From this point of view, most of the professional organisms impose these requirements:

- requirements regarding professional training: special studies in the financial- accounting domain, preferably university studies specialized on accounting;

- experience regarding specific practice: before giving the free- practice right for the audit domain, the candidates must have a minimum specific practice number of years (for example, in an audit cabinet or accounting expertise)

- promoting a specific exam: this consists of a complex testing, where the accent is put on the disciplines of the accounting domain.

The professional working rules are made for the auditors in professional working guides that help in understanding the way in which audit evidence are collected for making opinions.

The report rules aim only for those audit missions that are finalized by a written report. These rules include, mainly, the rules that are to be respected in conceiving and making of the reports regarding financial situations of the economical agents. 


\section{Evolution of the International Audit Rules}

One of the characteristics of the financial audit is that at least 2 auditors, found in the same situation will have to reach at the same conclusions. In order to assure this homogeneity, the audit companies and professional organizations have taken measures that have been concretized as unitary methods' adopting and common approach. This does not mean that all the auditors act strictly identically, each cabinet developing methods and techniques that will lead to reliable conclusions (Thalassinos, 2008; Thalassinos and Kiriazidis, 2003).

The international rules that regulate the audit profession are American, and this is due to the fact that the USA is one of the countries with the vastest experience in what regards the financial audit domain.

The first financial audit standards (ISA) were made in the years 1939- 1951, by the AICPA, by a permanent committee regarding audit procedures.

By the year 1972, the actual standard collection was finalized, and the name of the committee was modified into the Audit Standards Executive Committee (Aud Sec), this also having the role to interpret the generally accepted audit standards (GAAS). In the year 1978, the AudSec was replaced by the Audit Standards Board (ASB), which had the task to establish the main rules the financial auditors must respect in their missions.

The AICPA established the professional conditions an authorized accounting expert must comply with. This institute has made studies and researches, has published papers regarding numerous and various subjects of the accounting, audit, certification, insurance and accounting/ fiscal consultation domains. Within the initiatives made by the AICPA in order to promote the services offered by authorized accounting experts are included: national publicity campaigns, making of professional certificates and efforts made by the Certification Services' Special Committee in conceiving and promoting new assuring services.

The AICPA, by its committee, has made new standards and rules that can be classified as follows:

- audit standards 
- compilation and reviewing standards

- other certification standards

- the professional behavior code.

The ASB is responsible for publishing certain recommendations regarding various subjects connected to the audit. These recommendations are called Statements on Auditing Standards.

The Accounting and Review Services Committee makes recommendations regarding the responsibilities of the accounting experts, when these are involved in making financial situations of companies that are not listed and that do not make the object of an audit. One of the standards made by this committee, made in the year 1978, replaces all the former standard formulations regarding financial situations that have not made the object of an audit. This standard refers to two types of specific services and those are:

- the case where the accounting expert helps the client to make the financial situations, without offering any assurance in what regards the contents of the situations (compiling services)

- the case where the accounting expert makes a review and applies the analytical procedures which offer a relatively reasonable base in expressing a limited assurance that there are not significant modifications to be done in the financial situations (reviewing services).

In 1986, the American Authorized Accounting Experts Institute has published statements on Standards for Attestation Engagements. The purpose of this publication is double. On one side, it offers a reference area, which is to be respected by the standardization organizations in their standard defining activity, aiming only to specific certification services. On the other side, it offers an orientation area for the practitioners, in the case where no other standards exist.

The professional behavior code was made by the Committee on Professional Ethics, which is part of the AAAEI. The behavior rules apply to all the services made by the accounting experts and offer a reference area for the more technical standards.

In Great Britain, the main rules and regulations for the audit were made by the following professional organisms: The Chartered Institute of Management Accountants, The Institute of Chartered Accountants in England and Wales, The Chartered Institute of Public Finance and Accountancy, The Association of 
Chartered Certified Accountants, The Institute of Chartered Accountants of Scotland. The five mentioned professional organizations, members if the International Federation of Accountants, have determined clear regulations for the audit, that are mostly about technical standards for the audit, but also adopting an ethic behavior code. One of the most important measures taken in GB aimed to monitoring the quality if the made audit, especially for the public interest firms. After the monitoring was made, the existent relation between the auditor and the client was analyzed, and the way in which it affected the professional reasoning of the auditor and the audit opinion.

In France, the accountant profession is regulated by the Superior Council of the Accounting Experts' Order (CSOEC), and the National Accounts Commissars Company. The last mentioned organism is a member of the European Accounting Experts Federation, the International Accountants Federation and the International Accounting Standards Board. The main objectives that the professional organizations in France aim to are:

- developing the accountant profession in order to reach a highcompetence level;

- assisting the state institutions in the accounting normalization process;

- organizing training courses;

- cooperation with the international institutions (EU, World Bank, BERD) in order to make normalization and harmonization projects for the accounting and audit domain.

On an European level in the year 1989 the European Accounting Experts Federation (FEE) was established, located in Brussels, made by the reunion of the European Accounting Experts' Union and the Accounting Experts Group of the CEE. The FEE published recommendations regarding the accounting reviewing of the ASB.

At the base of the juridical function of the audit, on the European level, an important role is played by the European directives, the most important being the $8^{\text {th }}$ directive of April $10^{\text {th }} 1984$ regarding the legal control exerting conditions of the synthesis documents. This directive is considered to be the third concretization of the European accounting harmonization (the first two being the $4^{\text {th }}$ directive in 1978 and the $7^{\text {th }}$ in 1983). The objectives of the $8^{\text {th }}$ directive are:

- the harmonization of the qualifications of the persons able to make the legal control of the synthesis accounting documents; 
- assuring a increased level of theoretical knowledge and capacity to apply this knowledge in legal control practice;

- authorizing the persons and societies to do legal control.

The most important international organization in the audit domain is the IFAC, created in 1973 in New York. The mission of the IFAC is to develop the accounting and audit profession in order to allow it to assure superior- quality services for the public interest. The IFAC is a non-profit, non-governmental professional organization. By its cooperation with member and regional organizations, the IFAC initiates and coordinates the international normalization efforts from a technical, ethical and educational point of view. Within the IFAC, the permanent technical commissions are activating, in the following domains: education, ethics, financial and management accounting, information technology, international audit standards, international audit practices, international standards on professional services' quality, international standards on reviewing missions, relations with member organizations.

The International Audit Practices Committee is the department designated by the IFAC to make and develop the standards and declarations regarding the audit activity. The IAPC, by its activity, tries to harmonize the audit practices of the IFAC member countries and to minimize major differences, developing internationally applicable audit standards. These standards contain base principles and procedures, and also supplementary explanations and indications.

By the issued standards, the IFAC assures the international uniformity of the audit practices. In order to support member countries in implementing the international audit standards, the IFAC, by its IAPC, follows to promote and adapt these standards voluntarily. In order to obtain as much diverse opinions as possible, subcommittees made of specialists that are not IAPC represented can be made.

The international audit standards apply to the audit of the financial situations or in the case of connected services. International standards contain base principles and procedures, such as supplementary explanations and indications. For extraordinary situations, the auditor can consider detouring from the stipulations of one or more standards to reach the objective of its activity in a more efficient way. In such situations, the auditor must be prepared to justify his detour from the international audit standards. 
The international audit standards are exclusively applied to all the significant aspects. Any limitation of the applicability area of the international standards is clearly stipulated in the introductive paragraph of each standard. In some cases, the standards have at the end a paragraph that stipulates the specification of the public sector Committee. In the case that a standard does not contain such a paragraph, it is applicable to all the significant aspects of the public sector (Liapis, Rovolis and Galanos, 2010, 2012 and 2013, Thalassinos et al., 2010).

The international audit standards do not have a greater power than the national regulations of a certain country. If the national audit rules of a member country differ or are in conflict with the international standards, the professional organizations of the mentioned country must assure respect for the obligations of the IFAC members established in the constitution document.

In conclusion, it can be affirmed that the globalization and internationalization of the accounting profession have contributed to the development of the international audit standards. In the conditions of an obvious globalization, the investors and the capital markets' regulation organizations demand for more and more complete audit rules that are to attest the credibility of the world financial situations. The international audit standards are an assembly of reference practices created to improve the quality of the financial information on the international markets.

\section{Audit Standards In the Globalization Process}

The actual world, considered as an assembly, but mostly the actual economical world is in a continuous movement, manifesting as a permanent changing process. Today, we assist at a powerful globalization of commercial changes, of national economy forces and the never before growth of the financial markets' importance.

Within the nowadays globalization process, when the economical borders of the countries virtually disappear, and the businesses get a more international characteristic, the economical world has created an universal language of business, concretized in international accounting and audit standards.

In a globalized world, communication in the economical language in general, in the language of accounting and the one of financial audit especially demands unity in conceiving the organization and leading methods for the commercial, administration 
and resource control companies, and also unity of the principles and accounting methods to develop, present and audit the financial situations.

The International Standards of Accounting Reporting group (ISAR), which gathers more than 100 countries within the 25- 27 of September 2002 conference but also in the 2003 conference, has identified the obstacles the entities are facing in accounting leadership and quality financial information supply, and also some of the major difficulties that make hard to run the globalization process. Regarding the organization and leadership methods of the companies, within the mentioned conferences, the Corporate Governance concept was suggested (GC).

The CG, as an organization and leadership method for the commercial companies that stake the way the globalization goes on, is presented in the profile scientific literature by the Organization for Economic Cooperation and Development- OECD defined as: "the Corporate Governance is expressed by a set of relations between company management, its board, its shareholders, other title owners; nevertheless, it offers the structure that all the methods are established to reach these objectives and monitor the desired performances" [4]. The Corporate Governance is an art of leading, which varies in each country with the national legislative regulations, the complexity of the major stakeholders and specific conditions of the company, the complexity degree of the business, world economic status.

The FEE published, in July 2003, a very important document called „Financial Reporting and Auditing Aspects of Corporate Governance”, in which the followed are mentioned: „The FEE considers that the recommendations regarding Corporate Governance must be revised, so that they become efficient for the training and presentation of quality financial information, by applying the International Financial Reporting Standards.

The Corporate Governance is one of the numerous mechanisms that stimulate economical and social development along with [10]:

- the commercial and consume rights rules;

- respect to ownership right

- respect to the contract rights and obligations

- fiscal and cash discipline.

The principles of the corporate governance are mentioned in the IAS no. 260, "Communicating the Audit Aspects to the governance responsible”. There is no 
unique corporate governance model at a global level. The structures of the leading boards and practices vary with each country. A common principle is that the entity must dispose of a governance structure that allows the board to exert an objective reasoning regarding the society business, including independent financial reporting. The corporate governance principles focus especially on the companies that are listed. Problems that appear along the financial situation audit must be declared to the governance responsible. Audit problems, highly important to the governance are those problems that appear in auditing financial situations and which, in the auditor's opinion, are also important and relevant for the governance responsible in surveying the financial reporting and information presentation processes [10].

The IAS 240, "responsibility of the auditor to take into consideration fraud and error in a financial situations audit engagement” stipulates that the primary responsibility in fraud and error prevention belong to the governance responsible and the board of the entity. The board, under the survey of the governance responsible, must create an adequate climate and establish correspondent controls for preventing and detecting the frauds and errors within the entity.

The auditor must take into consideration the problems that appear as a consequence of the financial situations' audit and communicate them to the governance responsible. Such problems may refer to:

- modifying the accounting policies and practices;

- $\quad$ possible effect over the financial situations of significant risks;

- $\quad$ audit adjustments, recorded or not by the entity, that have or may have a significant impact over the financial situations of the entity;

- $\quad$ important uncertainties that may doubt the capacity of the entity to continue its activity;

- disagreements with the board regarding certain problems which, individually or cumulated, could be important for the entity's financial situations;

- other aspects, such as significant debts in the intern control, frauds that involve management, that elicit the interest of the governance responsible.

IAS 315, called "comprehension of the entity and its environment and evaluating the significant misrepresentation risks" warns the auditor and highlights the importance of intern control, identifying and evaluating the risks of the financial situation's existence risks and misinterpretations, and also the opportunity of a 
systematical and permanent communication with the persons tasked with governance and management.

\section{Conclusion}

It is remarked the fact that the international audit rules make an eloquent reference in harmonizing with the international standards and the European directives of the financial audit. The audit standards taken by our country apply in auditing the financial situations by financial auditors, members of the CECCAR. Financial auditors, persons or companies, activate in the domains of financial audit, internal audit, and also financial, accounting and fiscal consultancy, assuring financial and accounting management and professional special training in the domain.

In conclusion, one fact must be highlighted: that internationally there are clearly established objectives in what regards corporate governance, which is taken as an economical phenomenon in the long road of globalization. In almost all the countries there are preoccupations and direct actions that aim to the protection of the shareholders, power balance within the company boards, extension of the legal audit and audit committee making, organizing internal control, understanding of the transparency significance and financial information quality. In this context, the role is obvious for the globalization process of the International Accounting Standards, the International Financial Reporting Standards and the International Audit Standards.

\section{References}

Arens, A.A. and Loebbecke, J.K. (2003), “Audit - o abordare integrată”, Ed. Arc, Chişinău, p.395.

Boulescu, M., Brânză, C., and Preda, B. (2005), "Expertiză contabilă şi audit financiar contabil”, Aplicaţii şi studii de caz, Ed. Fundaţiei România de Mâine, Bucureşti.

Florea, I., Macovei, I.C., Florea, R. and Berheci, M. (2005), "Introducere în expertiza contabilă şi auditul financiar”, Ed. CECCAR, Bucureşti.

Ghizari, E.J., Rusovici, A., Rusu, G. and Cojoc, F. (2006), “Auditul situaţiilor financiare în entităţile economice”, R.A. Monitorul Oficial, Bucureşti, p.125.

Guy, D.M., Alderman, C.W. and Winters A.J. (1999), “Auditing”, ediţia a $V$-a, The Dryden Press, Londra, citat de A. Munteanu în Auditul sistemelor informaţionale, Ed. Polirom, Iaşi, pp.145. 
Hlaciuc, E. and Tulvinschi, M. (2005), “The Risks of Financial-Accounting Audit and Their Relative Importance", International Conference on Finance and Banking, Silesion University Opava, School of Business Administration, Czech Republic, pp.1715-1731.

Iancu, E. and Morariu, N. (2009), “Accounting aspects seen in the point of view of the expert systems”, Buletin UASVM, 66(2)/2009, Cluj Napoca, ISSN 1843-5254, electronic ISSN 1843-5394, Buletinele USAMV sunt indexate in ISI proceeding (WEB of Knowledge), pg.243-245.

Iancu, E., Grosu, V. and Socaciu, T. (2009), "Information technologies and communications in all fields of economic activity and financial”, New Challenges In The Field Of Military Sciences 2009, $6^{\text {th }}$ International Conference 18 - 19 November, 2009, ISBN 978-963-87706-4-6, Budapest, Hungary.

Liapis, K., Rovolis, A. and Galanos, C. (2013), “The Tax Regimes of the EU Countries: Trends, Similarities and Differences”, Chapter k book in A. Karasavvoglou and P. Polychronidou (eds.), Economic Crisis in Europe and the Balkans, Contributions to Economics, Springer International Publishing Switzerland, DOI IO.1007/978-3-31900494-5_6, 119-145.

Liapis, K., Rovolis, A. and Galanos, C. (2012), “Toward a Common Tax Regime for the European Union Countries,” European Research Studies Journal, Vol. XV, Issue (3), 67-98.

Liapis, K., Rovolis, A. and Galanos, C. (2010), “Accounting GAAPs and Accounting Treatments for Management of Property: Case Studies from Greek Real Estate Market European Research Studies Journal, Vol. XIII, Issue (3),

Raffegeun J.A. Ritz 1986- Audit et informatique, Presses Universitaires de France, Paris, 1986, p.42.

Thalassinos, I.E., Liapis, K. and Thalassinos, E.J. (2011a), “The Regulation Framework for the Banking Sector: The EMU, European Banks and rating Agencies before and During the Recent Financial and Debt Crisis”, Annals Economic Science Series, Vol. 1, issue 39, 250-279.

Thalassinos, I.E., Liapis, K. and Thalassinos, E.J. (2011b), “A Holistic Framework for Measuring a Bank’s Financial Health, Available at SSRN1787626 http://ssrn.com/abstract $=1787626$

Thalassinos, I.E., Deceanu, L., Pintea, M. and Zampeta, V. (2010), “New Dimensions of Country Risk in the Context of the Current Crisis: A Case Study for Romania and Greece”, European Research Studies Journal, Vol. XIII, (3), pp. 225-236.

Thalassinos, E. and Kiriazidis, Th. (2003), "Degrees of Integration in International Portfolio Diversification: Effective Systemic Risk”, European Research Studies Journal, Vol. VI, Issue 1-2, pp. 111-122. 
International Journal of Economics \& Business Administration, I (2), 2013

Thalassinos, E. (2008), “Trends and Developments in the European Financial Sector", European Financial and Accounting Journal, Vol. 3, No. 3, pp. 51-68.

Tulvinschi, M. (2008), “Auditul financiar: abordari teoretice si practice”, Editura Sedcom Libris, Iasi, ISBN 978-973-670-292-1. 